\title{
Perbaikan MPPT Incremental Conductance menggunakan ANN pada Berbayang Sebagian dengan Hubungan Paralel
}

\author{
MUHAMMAD NIZAR HABIBI, DIMAS NUR PRAKOSO, NOVIE AYUB \\ WINDARKO, ANANG TJAHJONO
}

\author{
Teknik Elektro Politeknik Elektronika Negeri Surabaya, Indonesia \\ Email: nizaarhabibi@gmail.com
}

Received 19 Maret 2020 | Revised 30 Maret 2020 | Accepted 25 April 2020

\begin{abstract}
ABSTRAK
Algoritma Incremental Conductance (IC) adalah algoritma yang bisa diimplementasikan pada sistem Maximum Power Point Tracking (MPPT) untuk mendapatkan daya maksimum dari panel surya. Akan tetapi algoritma MPPT IC tidak bisa bekerja dikondisi berbayang sebagian, karena menimbulkan daya maksimum lebih dari satu. Artificial Neural Network (ANN) bisa mengidentifikasi kurva karakteristik pada kondisi berbayang sebagian dan dapat mengetahui posisi daya maksimum yang sebenarnya. Masukan dari ANN merupakan nilai arus hubung singkat serta tegangan buka dari panel surya, dan keluaran dari ANN adalah nilai duty cycle yang digunakan sebagai posisi awal tracking dari MPPT IC. Data learning didapatkan dari perubahan nilai duty cycle secara manual pada sistem MPPT di berbagai kondisi radiasi. Hasil pengujian menunjukkan algoritma yang diajukan dapat menaikkan energi 5.79\%-13.32\% dibandingkan dengan ANNPerturb and Observe dan ANN-Incremental Resistance dengan durasi 0.6 detik.
\end{abstract}

Kata kunci: MPPT, Incremental Conductance, Artficial Neural Network, Berbayang Sebagian, Hubungan Paralel

\begin{abstract}
The Incremental Conductance (IC) algorithm is an algorithm that can be implemented on Maximum Power Point Tracking (MPPT) systems to get maximum power from solar panels. However, the MPPT IC algorithm cannot work in partial shading conditions because it causes more than one maximum power. Artificial Neural Network (ANN) can identify characteristic curves under partial shading conditions and can know the actual maximum power position. The input from ANN is the short circuit current and the open voltage of the solar panel. The output of ANN is the duty cycle value that is used as the initial tracking position of the MPPT IC. Learning data is obtained from manually changing the duty cycle value in the MPPT system in various radiation conditions. The test results show the proposed algorithm can increase energy 5.79\% -13.32\% when compared with ANN-Perturb and Observe and ANN-Incremental Resistance with a duration of 0.6 seconds.
\end{abstract}

Keywords: Maximum Power Point Tracking, Incremental Conductance, Artficial Neural Network, Partial Shading, Parallel Connection 
Perbaikan MPPT Incremental Conductance menggunakan ANN pada Berbayang Sebagian dengan Hubungan Paralel

\section{PENDAHULUAN}

Perkembangan teknologi secara global meningkat secara signifikan, begitu juga dengan energi terbarukan. Potensi Energi terbarukan sangat besar, hampir setengah dari kebutuhan global, pengembangannya yang begitu cepat sehingga bisa menjadi sumber energi terbesar pada tahun 2040 (BP Energy Outlook, 2019). Salah satu sumber energi terbarukan yang sangat efisien yaitu energi surya. Energi ini bisa diubah menjadi daya listrik dengan memanfaatkan panel surya. Pada umumnya, energi yang dihasilkan oleh panel surya pada siang hari akan disimpan ke dalam baterai dan pada malam hari akan digunakan sebagai pasokan lampu atau peralatan rumah tangga yang memerlukan daya listrik. Panel surya ini juga bisa langsung digunakan tanpa baterai, akan tetapi karakteristik tegangan dan arus panel surya tidak linier, karena kelemahannya ada pada rendahnya efisiensi konversi menjadi daya listrik dan bergantung penuh pada faktor lingkungan yaitu radiasi matahari dan suhu atmosfer. Besarnya nilai daya listrik yang dihasilkan oleh panel surya juga bergantung dari spesifikasi-spesifikasi parameter pada panel surya yang digunakan. Parameter yang jelas terlihat dari berbagai panel surya adalah dari parameter arus hubung singkat (ISC) dan tegangan buka (Voc) (Kurnia, dkk, 2013).

Untuk mendapatkan daya listrik maksimum dari panel surya diharuskan menggunakan teknik tracking, hal ini dilakukan untuk meningkatkan efisiensi konversi energi dari panel surya. Beberapa teknik tracking yang populer adalah Maximum Power Point Tracking (MPPT), dan Solar Tracking System. Teknik MPPT terdiri dari algoritma yang diimplementasikan ke sistem mikrokontroler yang diintegrasikan dengan konverter daya, dan sensor. Solar Power Tracking umunya merupakan sebuah device yang digunakan untuk menggerakkan panel surya, dan pergerakan tersebut mengikuti arah pergerakan dari matahari. Oleh karena itu, MPPT memiliki keunggulan dalam hal tidak membutuhkan komponen yang besar, sistem tidak kompleks, mudah dalam perakitan, dan relatif lebih murah (Habibi, dkk, 2019).

Saat ini sudah banyak sekali perkembangan metode MPPT, mulai dari yang konvensional hingga sampai berbasis komputasi. Contoh metode konvensional MPPT adalah Perturb and Observe (P\&O) (Kamran, dkk, 2018), dan Incremental Conductance (IC) (Necaibia, dkk, 2019). Keunggulan dari algoritma MPPT Perturb and Observe serta Incremental Conductance adalah mampu untuk mencari daya maksimum panel surya berdasarkan data dari tegangan dan arus yang timbul serta tidak memperhatikan karakteristik dari panel surya yang digunakan, berkerja cukup baik dalam berbagai kondisi radiasi matahari, dan mudah implementasi dalam kontrol digital (Sera, dkk, 2013). Akan tetapi jika kedua algoritma tersebut dibandingkan, maka algoritma Incremental Conductance lebih unggul dan hal kestabilan mendapatkan daya maksimum dari panel surya atau Maximum Power Point (MPP) serta memiliki osilasi yang rendah jika berada pada daerah MPP (Khadidja, dkk, 2017).

Akan tetapi algoritma Incremental Conductance hanya bisa bekerja jika karakteristik panel surya terkena radiasi normal, sedangkan dalam praktiknya ada kondisi radiasi dari matahari tidak bisa diterima oleh panel surya secara normal atau bisa disebut kondisi berbayang sebagian ( partial shading). Metode MPPT konvensional tidak bisa bekerja di kondisi berbayang sebagian dikarenakan pada kurva karakteristik panel surya muncul beberapa titik maksimum yang disebabkan oleh adanya diode bypass, dan digunakan menghindari hot spot (Mohapatra, dkk, 2017). Titik dengan nilai tertinggi merupakan Global Maximum Power Point (GMPP), dan titik tertinggi kedua dan seterusnya merupakan Local Maximum Power Point (LMPP). Sehingga diperlukan modifikasi atau perbaikan untuk metode MPPT konvensional khususnya algoritma Incremental Conductance agar bisa bekerja pada kondisi berbayang sebagian. 
Metode MPPT yang bisa bekerja dalam kondisi berbayang sebagian merupakan metode MPPT yang berbasis komputasi seperti Differential Evolution (DE) (Tey, dkk, 2014), Fuzzy Logic (Allataifeh, dkk, 2015), dan Artificial Neural Network (ANN) (Bouselham, dkk, 2017). Metode ANN berbasis MPPT memiliki ciri khas yang tidak dimiliki oleh metode berbasis komputasi yang lain, yaitu memiliki proses learning. Proses learning membantu metode ANN untuk mengenali terlebih dahulu karakteristik panel surya. Sehingga ANN dengan mudah bisa menentukan letak MPP berada atau jika kondisi berbayang sebagian yaitu letak GMPP berada. Keunggulan lain yang dimiliki oleh algoritma Artificial Neural Network (ANN) adalah memiliki respon kecepatan yang tinggi, operasi yang kuat, minim usaha komputasi karena ANN tidak membutuhkan komputasi yang kompleks dan rumit, serta dapat dijadikan solusi untuk masalah yang multi-variabel (Elobaid, dkk, 2015).

Dalam makalah ini disusun algoritma yang merupakan perbaikan dari algoritma Incremental Conductance (IC) dengan menggunakan algoritma Artificial Neural Network (ANN), sehingga algoritma bisa bekerja dalam kondisi berbayang sebagian. Jenis karakteristik berbayang sebagian yang dibentuk merupakan kombinasi dari dua panel surya yang diberi nilai radiasi matahari yang berbeda. Sehingga akan tercipta dua nilai puncak yaitu satu Global Maximum Power Point (GMPP) serta satu nilai puncak Local Maximum Power Point (LMPP). Oleh karena itu bisa saja letak GMPP berada di sebelah kiri atau sebelah kanan dari kurva karakteristik panel surya. Algoritma ANN akan mendeteksi letak GMPP yang diciptakan oleh kombinasi radiasi matahari pada panel surya, dan kemudian menentukan titik awal tracking MPPT dari algoritma Incremental Conductance. Algoritma MPPT Incremental Conductance dilengkapi dengan Variable Step Size, yang memungkinkan nilai step size yang berubah-ubah. Jika algoritma sudah mencapai nilai MPP atau GMPP dari panel surya maka nilai step size akan direduksi sehingga bisa menghilangkan ripple MPP.

\section{METODOLOGI PENELITIAN}

\subsection{Rangkaian Ekuivalen Panel Surya}

Panel surya digunakan untuk mengonversi radiasi matahari menjadi energi listrik. Panel surya bisa dikaitkan secara seri maupun paralel. Sistem panel surya menunjukkan hasil kurva I-V dan P-V yang non linier yang tergantung pada perubahan suhu dan radiasi yang ada pada saat itu. Rangkaian ekuivalen panel surya ini diwakili oleh satu sumber arus, satu dioda yang terhubung paralel dengan sumber arus, satu resistor yang terhubung paralel dengan sumber arus dan diode, satu seri resistor, dan terminal keluaran.

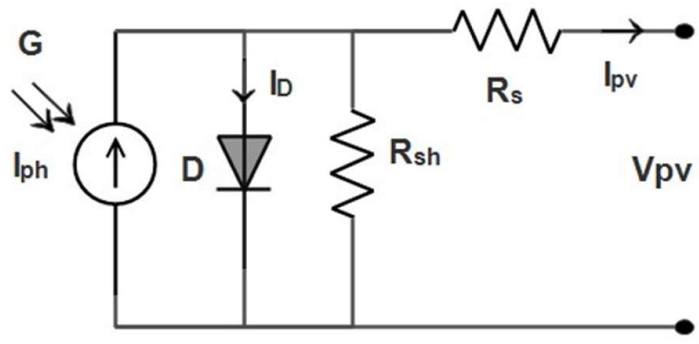

(a)

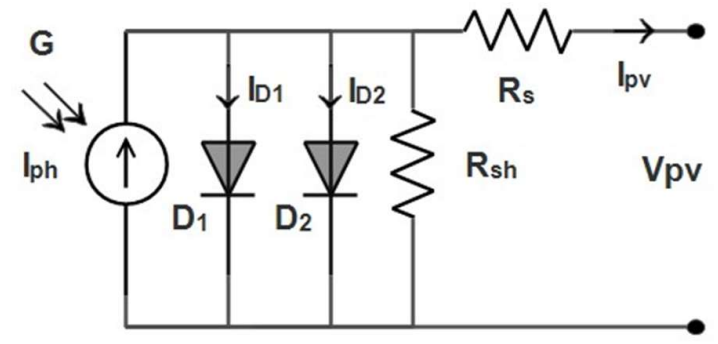

(b)

Gambar 1. Rangkaian Ekuivalen Panel Surya (a) Diode Tunggal (b) Diode Ganda

Gambar 1(a) adalah rangkaian ekuivalen dari model diode tunggal. Maka persamaan arus yang keluar dari panel surya berdasarkan rangkaian diode tunggal (Tamrakar, dkk, 2016) ditunjukkan pada Persamaan (1). 


$$
I_{p v}=I_{p h}-I_{s}\left(e^{\frac{V_{p v+I_{p v} R_{S}}}{n N_{s} V_{t}}}-1\right)-\frac{V_{p v}+I_{p v} R_{s}}{R_{s h}}
$$

Di mana, $I_{p v}$ dan $V_{p v}$ adalah arus dan terminal tegangan pada panel surya, $I_{p h}$ adalah arus yang dihasilkan ketika panel surya terkena iradiasi matahari, $I_{s}$ adalah arus jenuh, $n$ adalah faktor kualitas diode, $N_{S}$ adalah jumlah solar sel terhubung ke satu panel, $V_{t}$ adalah tegangan termal sel surya, serta $R_{s h}$ dan $R_{s}$ adalah paralel dan seri resistor panel surya. Arus yang dihasilkan oleh $I_{p h}$ sepenuhnya bergantung pada radiasi matahari yang dipaparkan oleh panel surya sehingga dapat disajikan pada Persamaan (2).

$$
I_{p h}=\frac{G}{1000}\left(I_{s c}+k_{i}\left(T-T_{r}\right)\right)
$$

Dengan $I_{s c}$ adalah arus hubung singkat dari panel surya, $G$ adalah nilai iradiasi matahari $\left(\mathrm{W} / \mathrm{m}^{2}\right), T_{r}$ adalah suhu sel surya, dan $k_{i}$ adalah koefisien suhu arus hubung singkat.

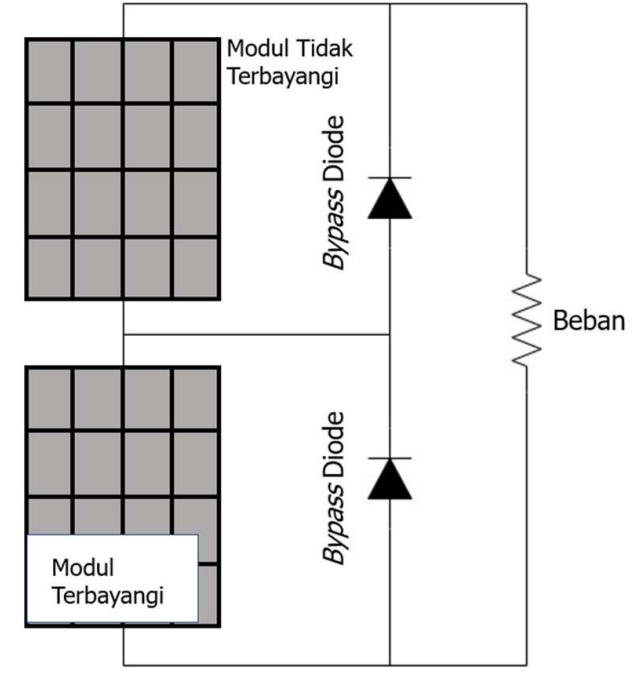

(a)

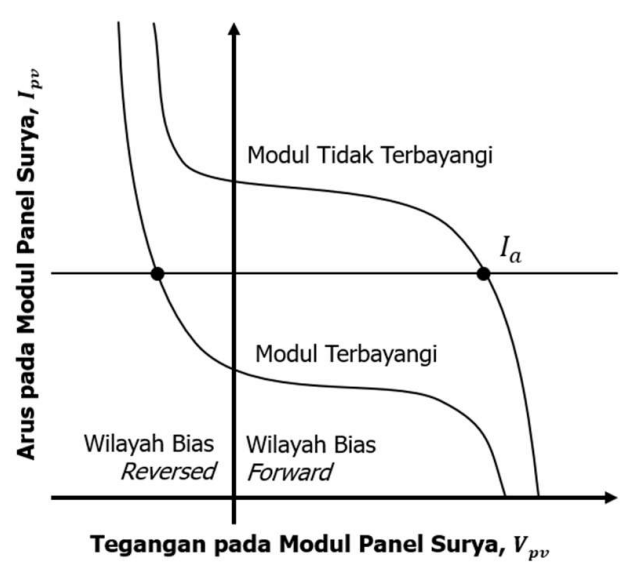

(b)

\section{Gambar 2. (a) Konfigurasi PV Array pada Kondisi Berbayang Sebagian (b) Karakteristik dari Modul Panel Surya}

Selain menggunakan rangkaian ekuivalen diode tunggal, model rangkaian ekuivalen dari panel surya yang lain adalah menggunakan diode ganda. Model ini terdiri dari dua diode yang diparalelkan dengan sumber arus. Sehingga akan timbul arus $I_{D_{1}}$ dan $I_{D_{2}}$ yang merupakan arus yang terjadi di diode pertama dan arus yang terjadi di diode kedua. Persamaan untuk model diode ganda (Windarko, dkk, 2020) ditunjukkan pada Persamaan (3).

$$
I_{p v}=I_{p h}-I_{S_{1}}\left(e^{\frac{V_{p v}+I_{p v} R_{S}}{n_{1} N_{S} V_{t}}}-1\right)-I_{S_{2}}\left(e^{\frac{V_{p v+I} I_{p v} R_{S}}{n_{2} N_{S} V t}}-1\right)-\frac{V_{p v}+I_{p v} R_{S}}{R_{S h}}
$$

$I_{s_{1}}$ adalah arus jenuh dari mekanisme difusi. $I_{S_{2}}$ adalah arus jenuh karena rekombinasi pembawa di wilayah ruang muatan, $n_{1}$ adalah faktor kualitas dari arus mekanisme difusi, $n_{2}$ adalah faktor kualitas dari arus rekombinasi generasi. Gambar 1(b) adalah rangkaian ekuivalen dari model diode ganda. 


\subsection{Karakteristik PV Array pada Kondisi Berbayang Sebagian (Partial Shading)}

PV Array merupakan suatu sistem yang terdiri dari modul-modul panel surya yang terhubung secara seri maupun paralel (Mahmoud, dkk, 2013), sehingga akan menghasilkan daya yang merupakan akumulasi dari banyaknya panel surya yang terhubung dalam PV array. Gambar 2(a) merupakan ilustrasi dari konfigurasi panel surya terbayangi, dengan penentuan posisi "modul terbayangi" ditentukan secara acak. Hal tersebut akan menghilangkan daya yang dihasilkan oleh panel surya yang lain (Tey, dkk, 2014). Untuk bentuk kurva yang dihasilkan oleh setiap modul panel surya ditunjukkan pada Gambar 2(b). Ketika panel surya beroperasi pada kondisi Ia, maka panel surya yang terkena berbayang sebagian akan memaksa untuk beroperasi pada wilayah bias reversed, sehingga akan memiliki sifat seperit beban, bukan seperti sumber.

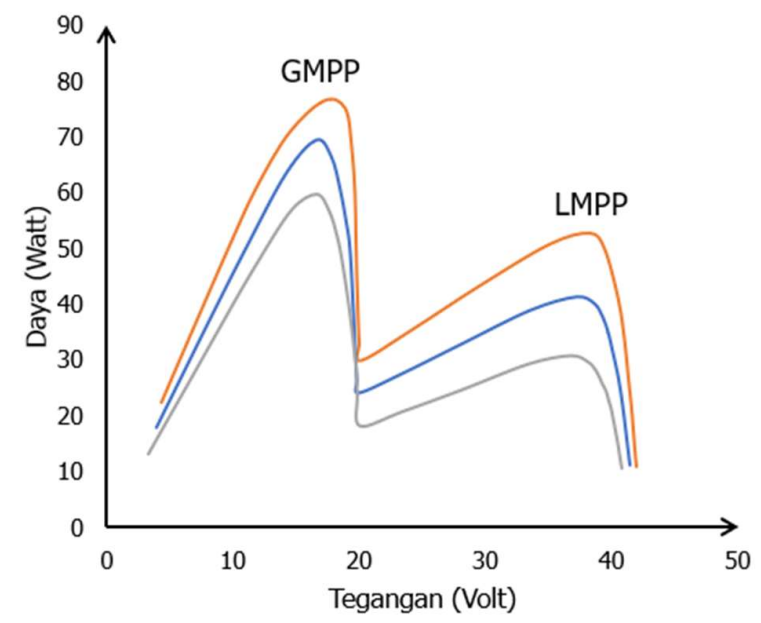

\section{Gambar 3. Kurva Karakteristik P-V dari Panel Suya pada Kondisi Berbayang Sebagian}

Fenomena tersebut akan menyebabkan disipasi daya sampai panas yang dapat mengakibatkan kerusakan pada modul panel surya yang terbayangi, sehingga bypass diode dipasang untuk menghindari kedua fenomena tersebut (Olalla, dkk, 2013) seperti yang ditunjukkan pada Gambar 2(a). Pada kondisi terkena radiasi matahari, diode bersifat bias reversed. Ketika terjadi berbayang sebagian pada panel surya, bypass diode bersifat bias forward dan arus melewati diode. Dan akibat dari adanya bypass diode, maka dalam kurva karakteristik panel surya muncul beberapa kurva Maximum Power Point (MPP). Kurva dengan puncak tertinggi bernama Global Maximum Power Point (GMPP) dan kurva dengan puncak tertinggi selanjutnya merupakan Local Maximum Power Point (LMPP) seperti yang ditunjukkan pada Gambar 3. Untuk kondisi berbayang sebagian, pada paper ini disederhanakan dengan menganggap radiasi berbeda pada masing-masing panel. Jadi definisi berbayang sebagian atau partial shading adalah perbedaan radiasi pada masing-masing panel surya. Efek yang ditimbulkan pada karakteristik P-V sama dengan berbayang sebagian (partial shading) pada sebuah panel surya.

\subsection{Penjelasan Umum Sistem}

Pada makalah ini disusun sistem untuk mencari daya maksimum dari panel surya atau GMPP untuk kondisi berbayang sebagian. Sistem terdiri dari dua sensor yang berfungsi sebagai sensor arus dan tegangan, satu konverter daya, sistem komputasi untuk implementasi algoritma, serta dua beban yang masing-masing berada pada masukan dan keluaran dari konverter daya seperti yang ditunjukkan pada Gambar 4. Pemasangan beban pada sumber konverter daya mengindikasikan bahwa sistem bekerja dengan hubungan paralel. 
Pemasangan sensor tetap pada daerah pertama kali timbul arus dan tegangan pada panel surya.

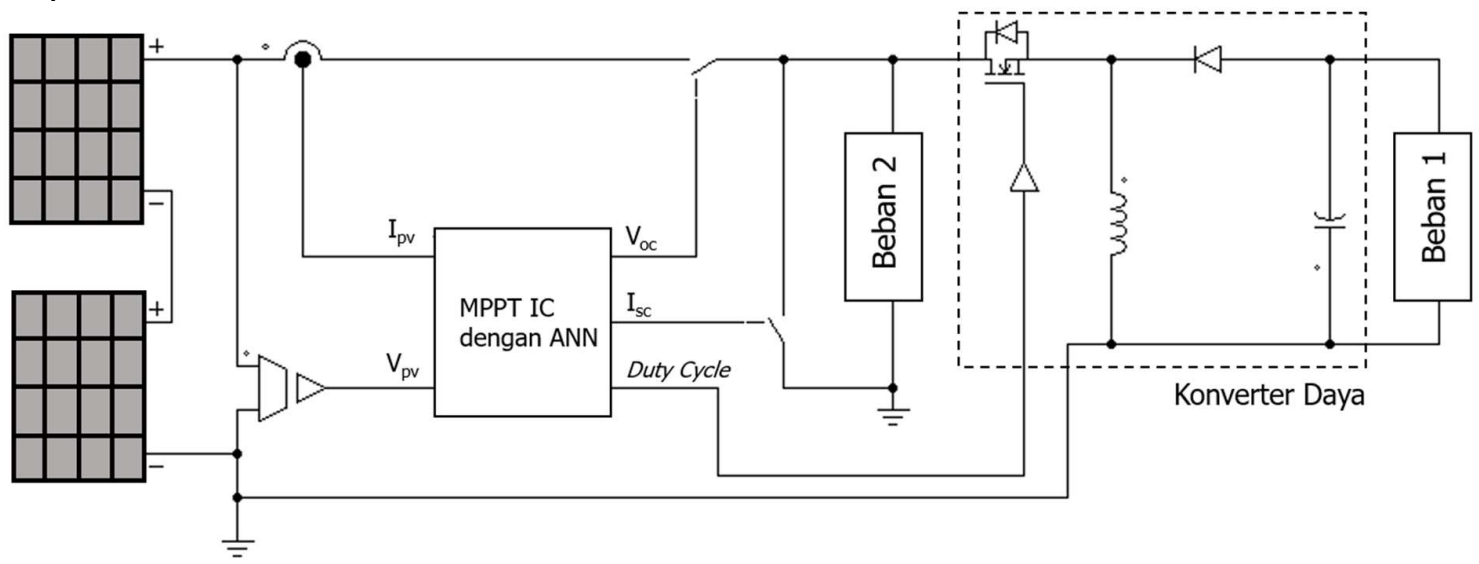

Gambar 4. Blok Diagram Sistem

\subsection{Algoritma MPPT}

Metode Incremental Conductance (IC) adalah metode yang mengatur perubahan terminal tegangan pada panel surya berdasarkan pada incremental dan instantaneous conductance pada panel surya. Konsep dasar dari algoritma Incremental Conductance ditunjukkan pada Gambar 5. Kemiringan pada kurva daya panel surya akan bernilai 0 (nol) ketika sudah mencapai daya maksimum, bernilai positif jika pada bagian kiri dari MPP, dan negatif jika berada pada bagian kanan MPP. Salah satu kelemahan yang dimiliki oleh algoritma Incremental Conductance adalah algoritma ini tidak bisa bekerja pada kondisi berbayang sebagian, sangat mudah sekali bagi algoritma Incremental Conductance untuk terjebak pada daerah Local Maximum Power Point (LMPP) dikarenakan penambahan dan pengurangan untuk proses tracking hanya dilakukan berdasarkan perubahan nilai arus dan tegangan yang timbul tanpa melakukan pengamatan karakteristik dari panel surya yang digunakan.

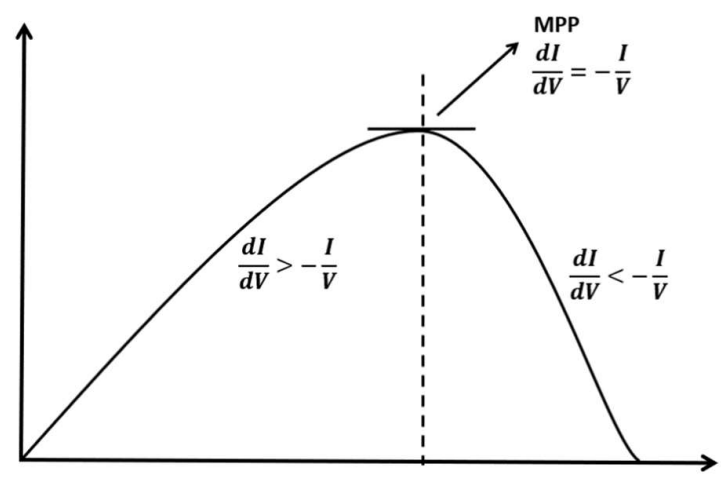

\section{Gambar 5. Konsep Algoritma Incremental Conductance}

Permasalahan yang timbul pada algoritma Incremental Conductance akan perbaiki oleh algoritma Artificial Neural Network (ANN). Algoritma ANN akan menganalisis terlebih dahulu jenis kurva karakteristik P-V panel surya, letak Global Maximum Power Point (GMPP) dari panel surya ada di sebelah kanan atau di sebelah kiri dari kurva. Gambar 6(a) merupakan bentuk arsitektur ANN yang digunakan. Arsitektur ANN terdiri dari dua masukan yang merupakan nilai dari arus hubung singkat dari panel surya serta tegangan buka dari panel surya. Arsitektur 
menggunakan satu hidden layer yang terdiri dari 13 neurons, pemilihan neuron berdasarkan pada nilai tertinggi dari pengujian Regresion Neural Network pada software MATLAB.

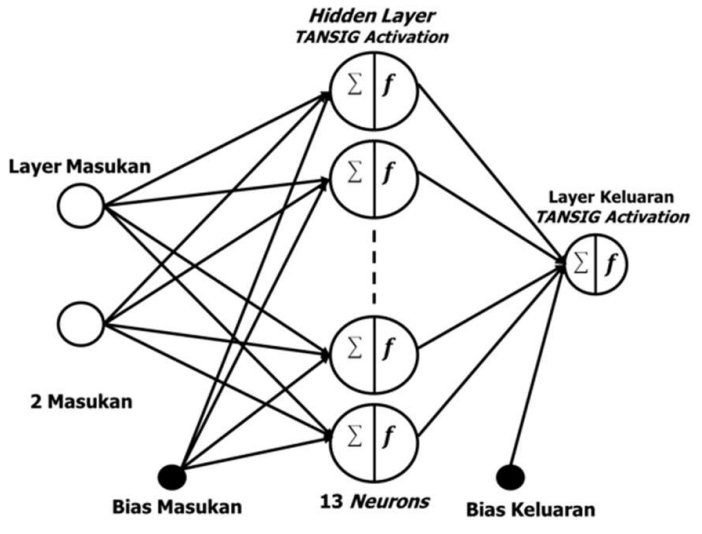

(a)

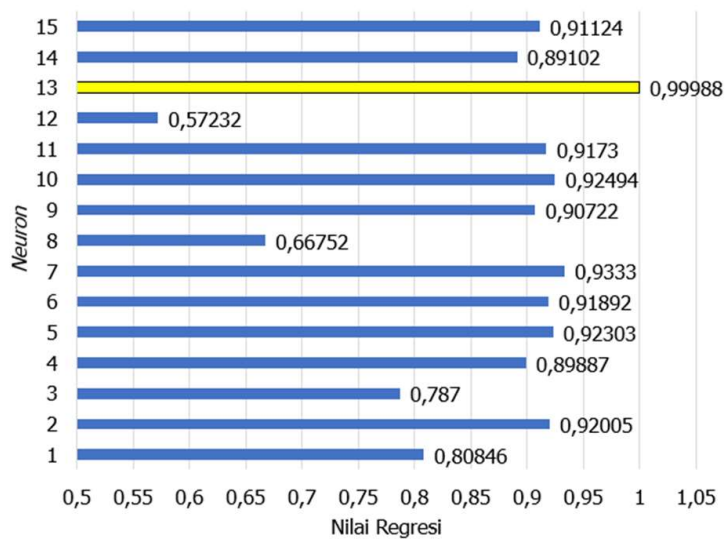

(b)

\section{Gambar 6. (a) Arsitektur ANN (b) Hasil dari Pengujian Neural Network Regression}

Gambar 6(b) menunjukkan hasil pengujian Neural Network Regression, pengujian dilakukan mulai neuron 1 sampai neuron ke-15. Nilai tertinggi merupakan nilai yang mendekati satu, dan pada neuron ke-13 didapatkan nilai tertinggi dengan nilai 0.99988. Jenis aktivasi yang digunakan pada hidden layer merupakan aktivasi tansig. Pada keluran ANN hanya terdapat satu jenis keluaran, yang merupakan posisi awal tracking dari algoritma Incremental Conductance. Sehingga ANN akan menganalisis terlebih dahulu jenis kurva berbayang sebagian, kemudian ANN akan menentukan posisi awal tracking dari algoritma Incremental Conductance. Pada masukan dari ANN perlu dilakukan normalisasi terlebih dahulu, persamaan normasilasi yang digunakan ditunjukkan pada Persamaan (4) dan Persamaan (5).

$$
\begin{aligned}
& X_{i n_{1}}=\frac{\left(I_{s c}-I_{s c_{\min }}\right) * 2}{\left(I_{s c_{\max }}-I_{s c_{\min }}\right)}-1 \\
& X_{i n_{2}}=\frac{\left(V_{o c}-V_{o c_{\min }}\right) * 2}{\left(V_{o c_{\max }}-V_{o c_{\min }}\right)}-1
\end{aligned}
$$

$X_{i n_{1}}$ dan $X_{i n_{2}}$ merupakan hasil normalisasi dari masukan pertama dan kedua. Arus $I_{s c}$ merupakan nilai arus hubung singkat dari panel surya, $I_{s c_{\max }}$ dan $I_{s c_{\min }}$ merupakan nilai arus hubung singkat terbesar dan terkecil dari panel surya berdasarkan data learning yang digunakan. Tegangan $V_{o c}$ merupakan nilai tegangan buka dari panel surya, $V_{o c_{\text {max }}}$ dan $V_{o c_{\min }}$ merupakan nilai tegangan buka terbesar dan terkecil dari panel surya berdasarkan data learning yang digunakan. Persamaan dari hidden layer dengan aktivasi tansig ditunjukkan pada Persamaan (6).

$$
T g_{1_{n}}=\frac{2}{\left(1+e^{\left(-2 *\left(\left(x_{i n_{1}} * w_{i_{n}}\right)+\left(x_{i n_{2}} * w_{i_{n}}\right)+b_{i_{n}}\right)\right)}\right)}-1
$$

Variabel $n$ menunjukkan jumlah neuron yang digunakan, $w_{i_{n}}$ dan $b_{i_{n}}$ merupakan nilai weight dan bias yang didapatkan saat melakukan proses pengujian neuron pada pengujian Neural Network Regression dengan menggunakan software MATLAB. Pada layer keluaran dari ANN 
menggunakan aktivasi tansig dan dilakukan proses normalisasi dengan Persamaan (7) dan Persamaan (8).

$$
\begin{aligned}
& T g_{2_{n}}=\frac{2}{\left(1+e^{\left(-2 * \sum_{n=1}^{13}\left(\left(T g_{1} * w_{i_{n}}\right)+b_{i_{n}}\right)\right)}\right)}-1 \\
& \alpha_{\text {start }}=\frac{\left(T g_{2_{n}}+1\right)\left(\alpha_{\max }-\alpha_{\min }\right)}{2}+\alpha_{\min }
\end{aligned}
$$

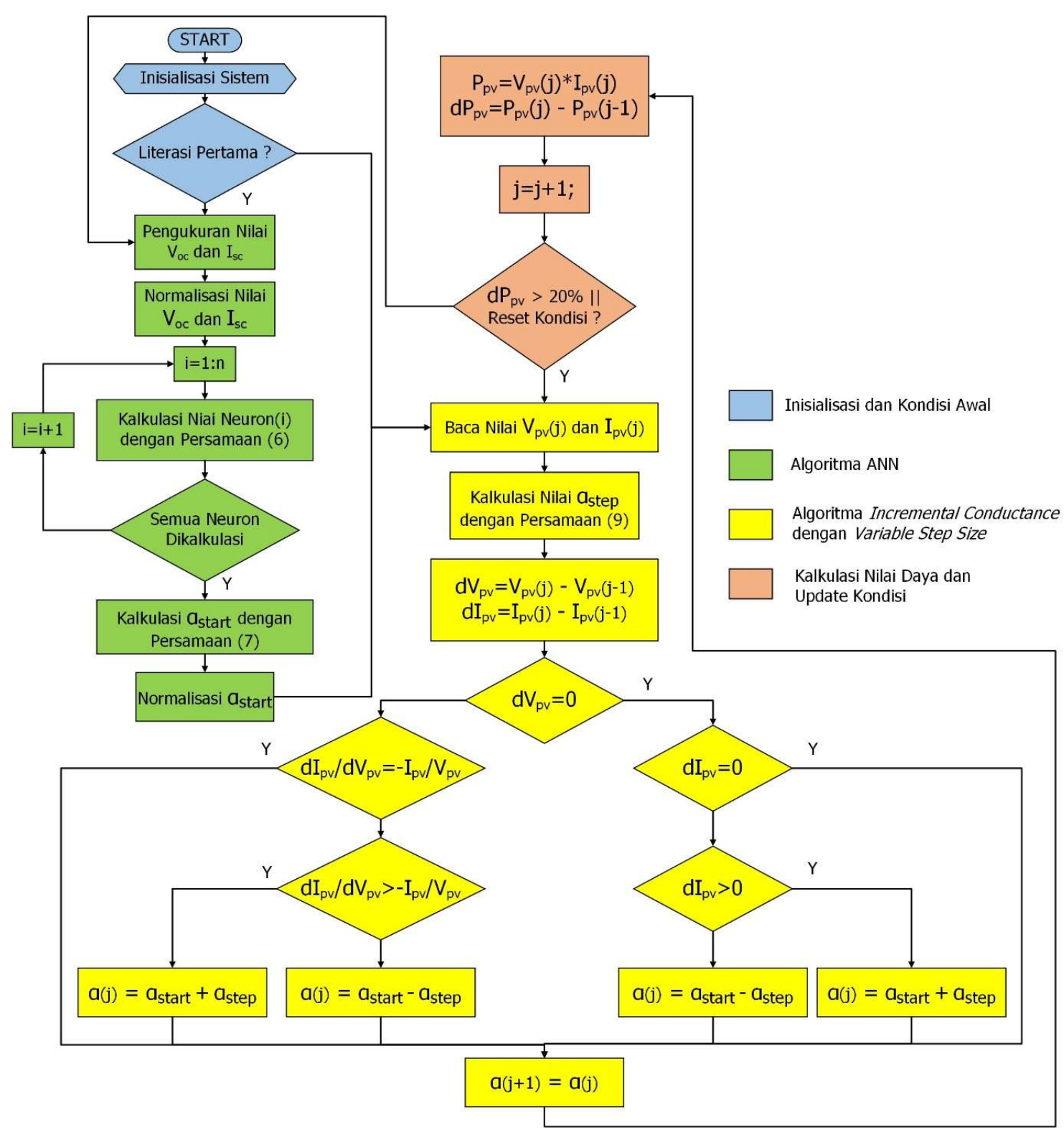

Gambar 7. Flowchart Sistem

Jenis keluaran yang digunakan merupakan nilai duty cycle posisi awal tracking, sehingga $\alpha_{\text {start }}$ merupakan nilai duty cycle tersebut. Variabel $\alpha_{\text {start }}$ hanya memiliki dua variasi nilai, yaitu $10 \%$ dan $90 \%$, sehingga $\alpha_{\max }$ dan $\alpha_{\min }$ adalah nilai duty cycle tertinggi bernilai $90 \%$ dan nilai duty 
cycle terendah bernilai $10 \%$ berdasarkan data learning yang digunakan. Gambar 7 menunjukkan alur kerja atau flowchart sistem dari algoritma yang diajukan. ANN bekerja terlebih dahulu untuk menganalisis karakteristik dari kurva yang diakibatkan oleh kondisi berbayang sebagian, kemudian algoritma Incremntal Conductance bekerja berdasarkan nilai duty cycle awal yang dihasilkan oleh ANN. MPPT Incremental Conductance dilengkapi dengan Variable Step Size yang digunakan untuk menghilangkan ripple saat algoritma sudah berada pada daerah GMPP. Persamaan yang digunakan pada Variable Step Size ditunjukkan pada Persamaan (9) (Isaloo, dkk, 2016).

$$
\alpha_{j}=\alpha_{j-1} \pm \frac{N}{I_{p v}}\left|\frac{d P_{p v}}{d V_{p v}}\right|
$$

Nilai $j$ menunjukkan jumlah literasi dari algoritma, $N$ adalah nilai konstanta dari Variable Step, sedangkan \pm menyesuaikan kondisi kerja dari algoritma Incremental Conductance berdasarkan pada Gambar 5.

\section{PENGUJIAN DAN ANALISIS}

Pengujian dilakukan menggunakan simulasi dengan software Power Simulation (PSIM). Pengujian dilakukan untuk mengetahui karakteristik dari algoritma yang diajukan. Pengujian algoritma akan dibandingkan terlebih dahulu dengan data learning yang digunakan, untuk menunjukkan kemiripan nilai yang didapatkan oleh algoritma. Gambar 8(a) menunjukkan bentuk karakteristik $P-V$ dari panel surya dengan radiasi $800 \mathrm{~W} / \mathrm{m}^{2}$ dan $500 \mathrm{~W} / \mathrm{m}^{2}$ yang didapatkan dari data learning.

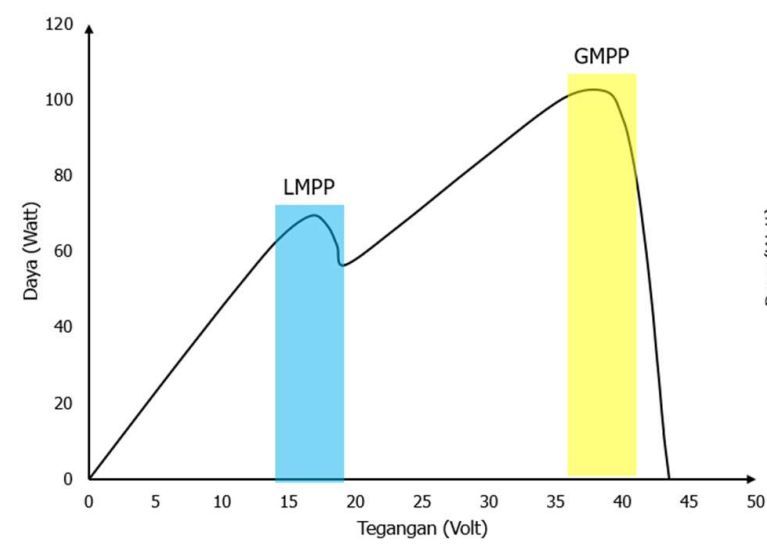

(a)

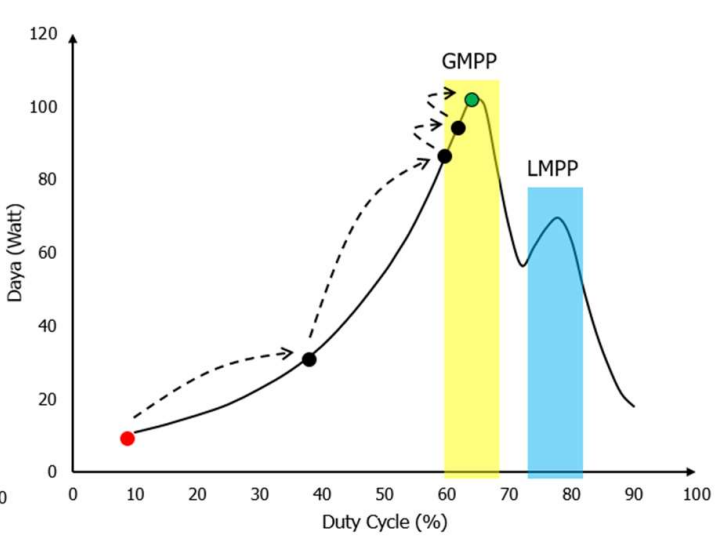

(b)

Gambar 8. Karakteristik Panel Surya Radiasi 800 W/m² dan 500 W/m² (a) Kurva P-V dari Data Learning (b) Hubungan Nilai Daya dan Duty Cycle

Daerah warna kuning menunjukkan daerah Global Maximum Power Point (GMPP), dan daerah warna biru merupakan daerah Local Global Maximum Power Point (LMPP). Gambar 8(a) juga menunjukkan bahwa letak GMPP ada di sebelah kiri kurva. Untuk lebih memperjelas hubungan nilai duty cycle dengan daya yang dihasilkan oleh panel surya ditunjukkan pada Gambar 8(b). Gambar 8(b) menunjukkan bahwa nilai duty cycle GMPP terletak pada sekitar nilai $60 \%$ sampai 70\%. Sehingga jika algoritma Incremental Conductance bisa berada di daerah GMPP maka posisi start duty cycle harus berada pada nilai $10 \%$. Jika posisi start duty cycle berada pada 90\% maka akan dipastikan algoritma terjebak pada daerah LMPP. Pada Gambar 8(b) juga menunjukkan proses tracking yang dilakukan oleh algoritma untuk bisa mencapai GMPP dengan titik warna merah adalah posisi awal tracking dan titik warna hijau merupakan titik 
duty cycle pada GMPP. Hasil pengujian secara simulasi berdasarkan karakteristik panel surya pada Gambar 8 ditunjukkan pada Gambar 9.
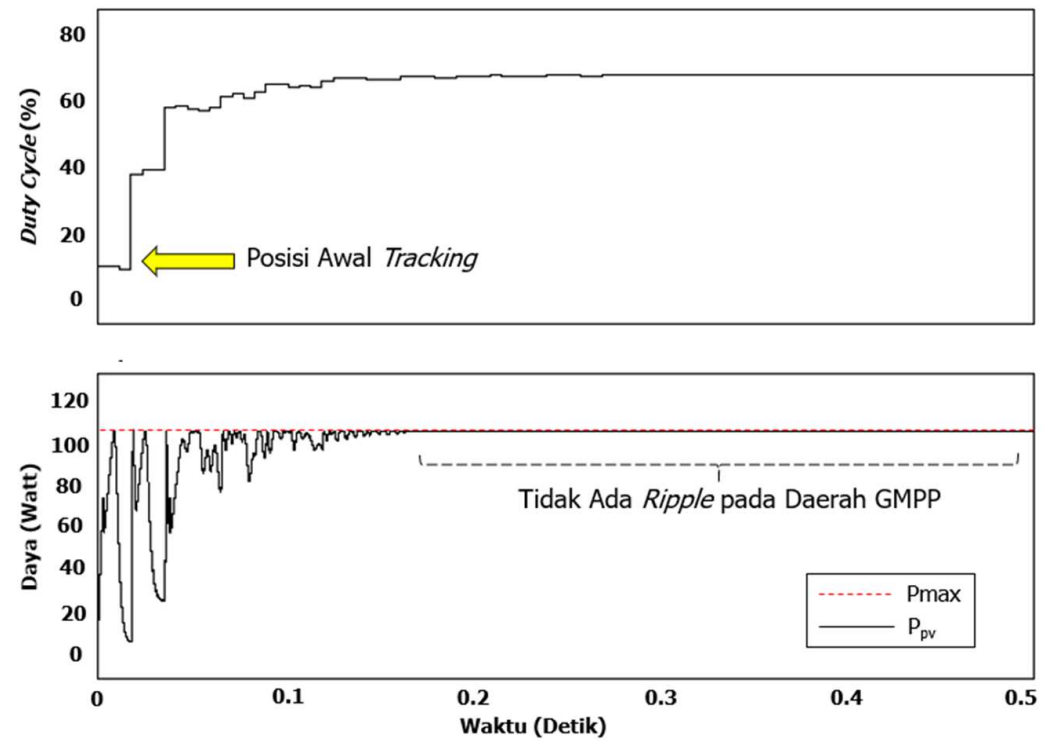

Gambar 9. Hasil Simulasi MPPT pada Radiasi $800 \mathrm{~W} / \mathrm{m}^{2}$ dan $500 \mathrm{~W} / \mathrm{m}^{2}$

Gambar 9 menunjukkan hasil nilai duty cycle yang dihasilkan ANN yaitu pada nilai 10\%, kemudian perindah-pindah sampai pada daerah GMPP. Hasil simulasi juga menunjukkan tidak ada ripple saat berada pada daerah GMPP, hal tersebut merupakan akibat dari persamaan variable step size yang menyebabkan tidak ada perubahan nilai pada daerah GMPP.

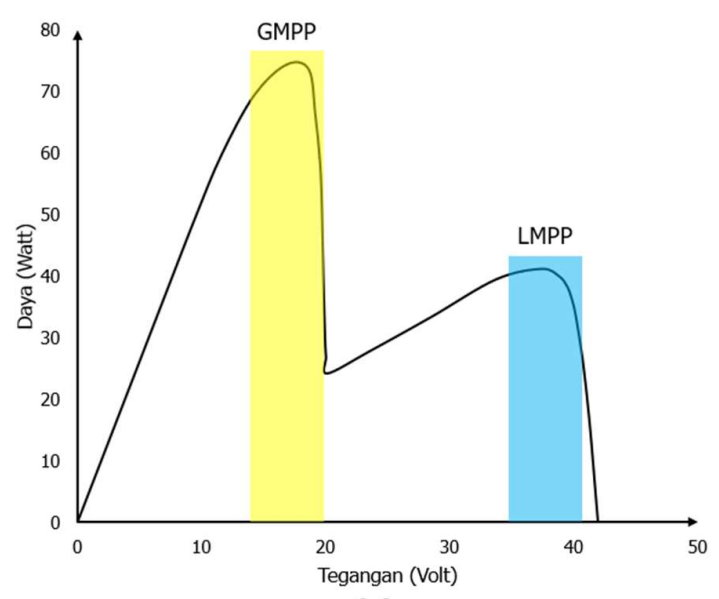

(a)

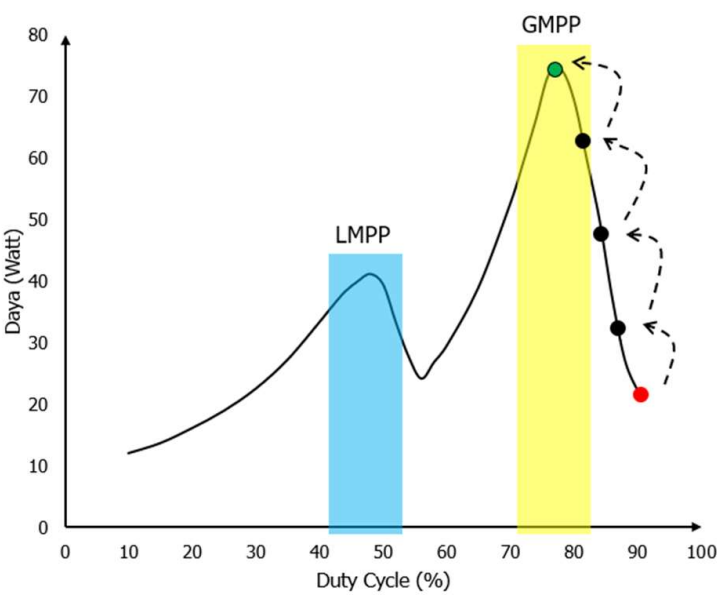

(b)

Gambar 10. Karakteristik Panel Surya Radiasi $900 \mathrm{~W} / \mathrm{m}^{2}$ dan $200 \mathrm{~W} / \mathrm{m}^{2}$ (a) Kurva P-V dari Data Learning (b) Hubungan Nilai Daya dan Duty Cycle

Pengujian selanjutnya merupakan pengujian dengan karakteristik P-V di sebelah kanan kurva seperti yang ditunjukkan pada Gambar 10(a). Pengujian dilakukan dengan menggunakan nilai radiasi matahari sebesar $900 \mathrm{~W} / \mathrm{m}^{2}$ dan $200 \mathrm{~W} / \mathrm{m}^{2}$. Untuk lebih memperjelas letak GMPP terhadap nilai duty cycle maka ditunjukkan pada Gambar 10(b). Gambar 10(b) menunjukkan bahwa letak GMPP untuk kombinasi radiasi $900 \mathrm{~W} / \mathrm{m}^{2}$ dan $200 \mathrm{~W} / \mathrm{m}^{2}$ terletak pada sekitar nilai $70 \%$ dan $80 \%$. Sehingga untuk bisa mencapai GMPP, nilai duty cycle start harus bernilai $90 \%$ agar algoritma tidak terjebak pada daerah LMPP. Gambar 14 juga dilengkapi dengan proses 
duty cycle dari start sampai mencapai daerah GMPP. Hasil simulasi respon duty cycle dan daya yang dihasilkan dengan nilai kombinasi radiasi matahari $900 \mathrm{~W} / \mathrm{m}^{2}$ dan $200 \mathrm{~W} / \mathrm{m}^{2}$ ditunjukkan pada Gambar 11.

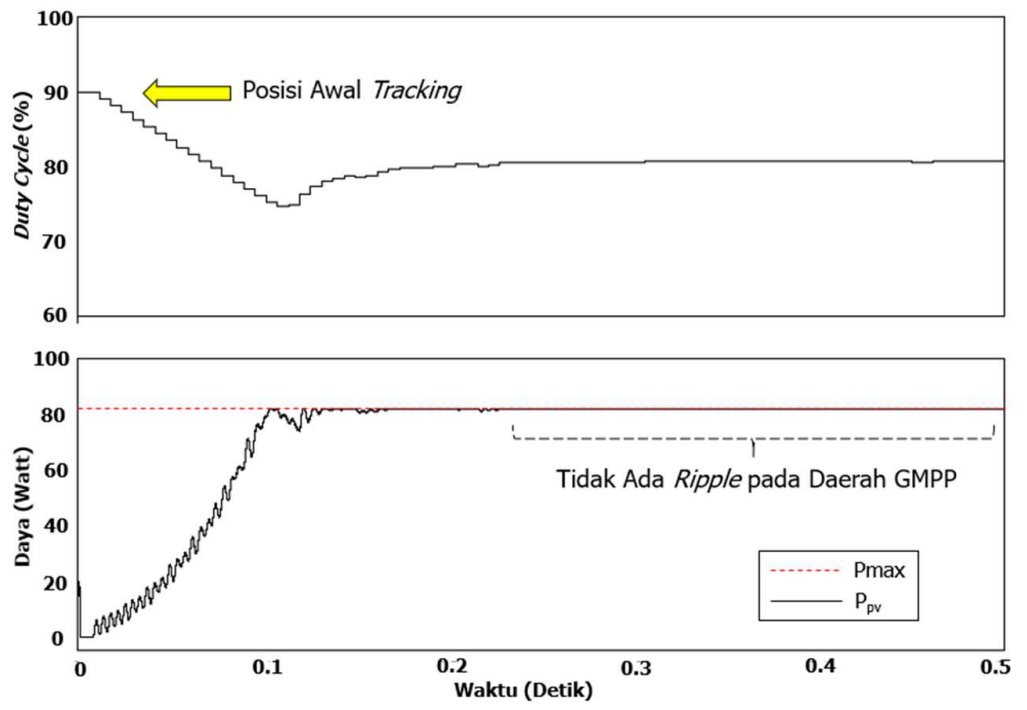

Gambar 11. Hasil Simulasi MPPT pada Radiasi 900 W/m² dan 200 W/m²

Hasil respon yang dihasilkan pada simulasi dengan kombinasi nilai radiasi sebesar $900 \mathrm{~W} / \mathrm{m}^{2}$ dengan $200 \mathrm{~W} / \mathrm{m}^{2}$ menunjukkan perbedaan jika dibandingkan dengan hasil simulasi sebelumnya. Karena nilai duty cycle start yang berbeda, maka respon yang dihasilkan juga berbeda. Pada Gambar 11 menunjukkan nilai duty cycle terus turun sampai pada daerah GMPP, dan pada daerah GMPP juga tidak terdapat ripple. Tabel 1 menunjukkan data untuk hasil pengujian dari algoritma yang diajukan.

Tabel 1. Hasil Pengujian MPPT

\begin{tabular}{|c|c|c|c|c|c|}
\hline \multirow{2}{*}{$\begin{array}{c}\text { Radiasi } \\
\text { Matahari }\end{array}$} & \multirow{2}{*}{$\begin{array}{c}\text { Duty Cycle } \\
\text { (W/m } \mathbf{m}^{\mathbf{2}} \text { ) }\end{array}$} & \multicolumn{2}{|c|}{ Datart (\%) } & \multicolumn{2}{c|}{ Algornitma } \\
\cline { 3 - 6 } & & MPP (W) & Duty Cycle (\%) & MPP (W) & Duty Cycle (\%) \\
\hline $900-200$ & 90 & 74.389 & 78 & 82.089 & 80.475 \\
\hline $800-200$ & 90 & 69.43 & 78 & 73.64 & 78.066 \\
\hline $750-150$ & 90 & 62.989 & 78 & 69.325 & 78.994 \\
\hline $600-100$ & 90 & 51.887 & 74 & 56.042 & 77.146 \\
\hline $800-500$ & 10 & 102.1 & 64 & 105.379 & 68.116 \\
\hline $750-400$ & 10 & 81.829 & 62 & 85.468 & 65.203 \\
\hline $700-450$ & 10 & 90.871 & 64 & 94.712 & 66.938 \\
\hline $650-450$ & 10 & 90.586 & 64 & 94.227 & 66.854 \\
\hline
\end{tabular}

Data pembanding dalam tabel tersebut merupakan nilai yang terdapat pada data learningyang digunakan. Hasil simulasi menunjukkan nilai yang mendekati dengan data learning yang digunakan. Nilai data learning memiliki nilai yan lebih rendah dari hasil simulasi karena nilai duty cycle yang diatur tidak berada pada daerah GMPP yang sebenarnya. Nilai duty cycle yang dihasilkan algoritma bisa bernilai tiga angka di belakang koma, dan bisa lebih presisi. Tabel 2 merupakan inisialisasi kondisi untuk pengujian panel surya berbayang sebagian selanjutnya. Ada 4 kondisi yang diinisialisasi mulai dari A, B, C, dan D. Kondisis A merupakan insialisasi kondisi untuk radiasi $1000 \mathrm{~W} / \mathrm{m}^{2}$ pada panel surya 1 dan $500 \mathrm{~W} / \mathrm{m}^{2}$ pada panel surya 2 . 
Kondisis B untuk radiasi $800 \mathrm{~W} / \mathrm{m}^{2}$ pada panel 1 dan $200 \mathrm{~W} / \mathrm{m}^{2}, \mathrm{C}$ untuk radiasi $900 \mathrm{~W} / \mathrm{m}^{2}$ pada panel 1 dan $500 \mathrm{~W} / \mathrm{m}^{2}$ pada panel 2 , dan $\mathrm{D}$ untuk radiasi $700 \mathrm{~W} / \mathrm{m}^{2}$ pada panel 1 dan $100 \mathrm{~W} / \mathrm{m}^{2}$ pada panel 2.

Tabel 2. Inisialisasi Kondisi Panel Surya

\begin{tabular}{|c|c|c|}
\hline $\begin{array}{c}\text { Radiasi Panel 1 } \\
\left(\mathbf{W} / \mathbf{m}^{\mathbf{2}} \mathbf{)}\right.\end{array}$ & $\begin{array}{c}\text { Radiasi Panel 2 } \\
\left(\mathbf{W} / \mathbf{m}^{\mathbf{2}} \mathbf{)}\right.\end{array}$ & Kondisi \\
\hline 1000 & 500 & $\mathrm{~A}$ \\
\hline 800 & 200 & $\mathrm{~B}$ \\
\hline 900 & 500 & $\mathrm{C}$ \\
\hline 700 & 100 & $\mathrm{D}$ \\
\hline
\end{tabular}

Gambar 12 merupakan hasil simulasi dengan dua algoritma pembanding. Algoritma yang digunakan sebagai pembanding merupakan algoritma Perturb and Observe dan algoritma Incremental Resistance yang digabungkan dengan ANN sebagai deteksi kondisi berbayang sebagian. Pemilihan algoritma pembanding didasarkan pada sifat dan karakteristik yang hampir sama dari ketiga algoritma konvensional tersebut (Incremental Conductance, Perturb and Observe, dan Incremental Resistance). Ketiga algoritma tersebut juga tidak bisa bekerja dalam kondisi berbayang sebagian, sehingga ketiga algoritma tersebut akan sama-sama mengalami proses perbaikan sehingga bisa bekerja dalam kondisi berbayang sebagian. Hal ini merupakan alasan mengapa algoritma yang diajukan tidak dibandingkan dengan algoritma Incremental Conductance yang tanpa perbaikan, karena akan dapat dipastikan algoritma tersebut terjebak dalam kondisi berbayang sebagian. Pengujian dilakukan menggunakan nilai radiasi konstan yaitu kombinasi $1000 \mathrm{~W} / \mathrm{m}^{2}$ dan $500 \mathrm{~W} / \mathrm{m}^{2}$ dengan kombinasi radiasi sebesar $800 \mathrm{~W} / \mathrm{m}^{2}$ dan $200 \mathrm{~W} / \mathrm{m}^{2}$.
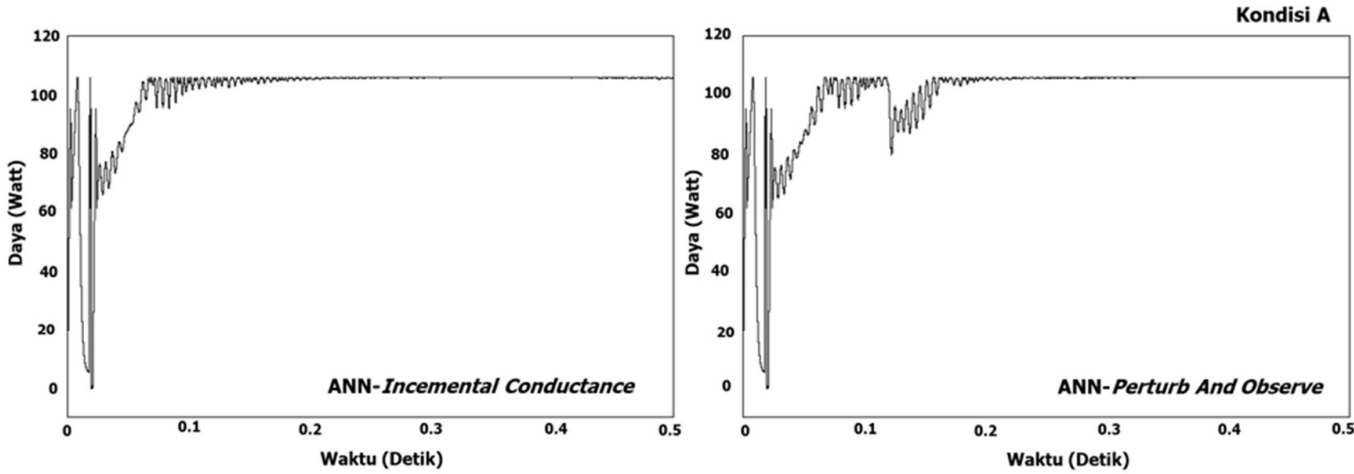

(a)
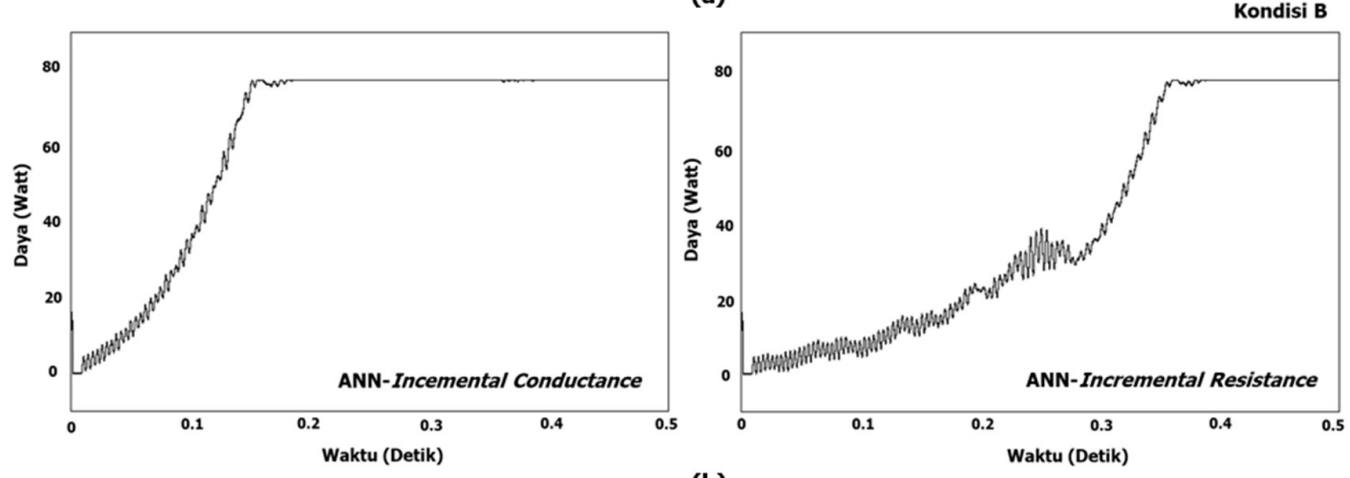

(b)

Gambar 12. Hasil Perbandingan Pengujian dengan Tiga Algoritma pada Nilai Radiasi Konstan 
Kedua pengujian tersebut dapat mewakili untuk kondisi nilai duty cycle start dengan nilai $10 \%$ dan 90\%. Pada kondisi A menunjukkan bahwa algoritma ANN-Incremental Conductance memiliki kurva respon yang lebih stabil untuk mencapai daerah GMPP jika dibandingkan dengan algoritma ANN-Perturb and Observe. Ketika kondisi panel surya pada kondisi B, ANNIncremental Resistance membutuhkan waktu yang lebih lama untuk bisa sampai ke daerah GMPP jika dibandingkan dengan ANN-Incremental Conductance. Gambar 13 merupakan perbandingkan dari ketiga algoritma ketika terjadi perubahan nilai radiasi matahari. Perubahan radiasi matahari terjadi pada detik ke-0.3 dengan total waktu yang digunakan 0.6 detik. Hasil pengujian menunjukkan pada kondisi $C$ algoritma yang diajukan memiliki kestabilan saat berada di GMPP, jika dibandingkan dengan algoritma yang lain. Pada saat kondisi radiasi matahari berubah menjadi kondisi D, algoritma lebih cepat menuju daerah GMPP dari panel surya. Energi yang dihasilkan berdasarkan Gambar 13 ditunjukkan pada Tabel 3.

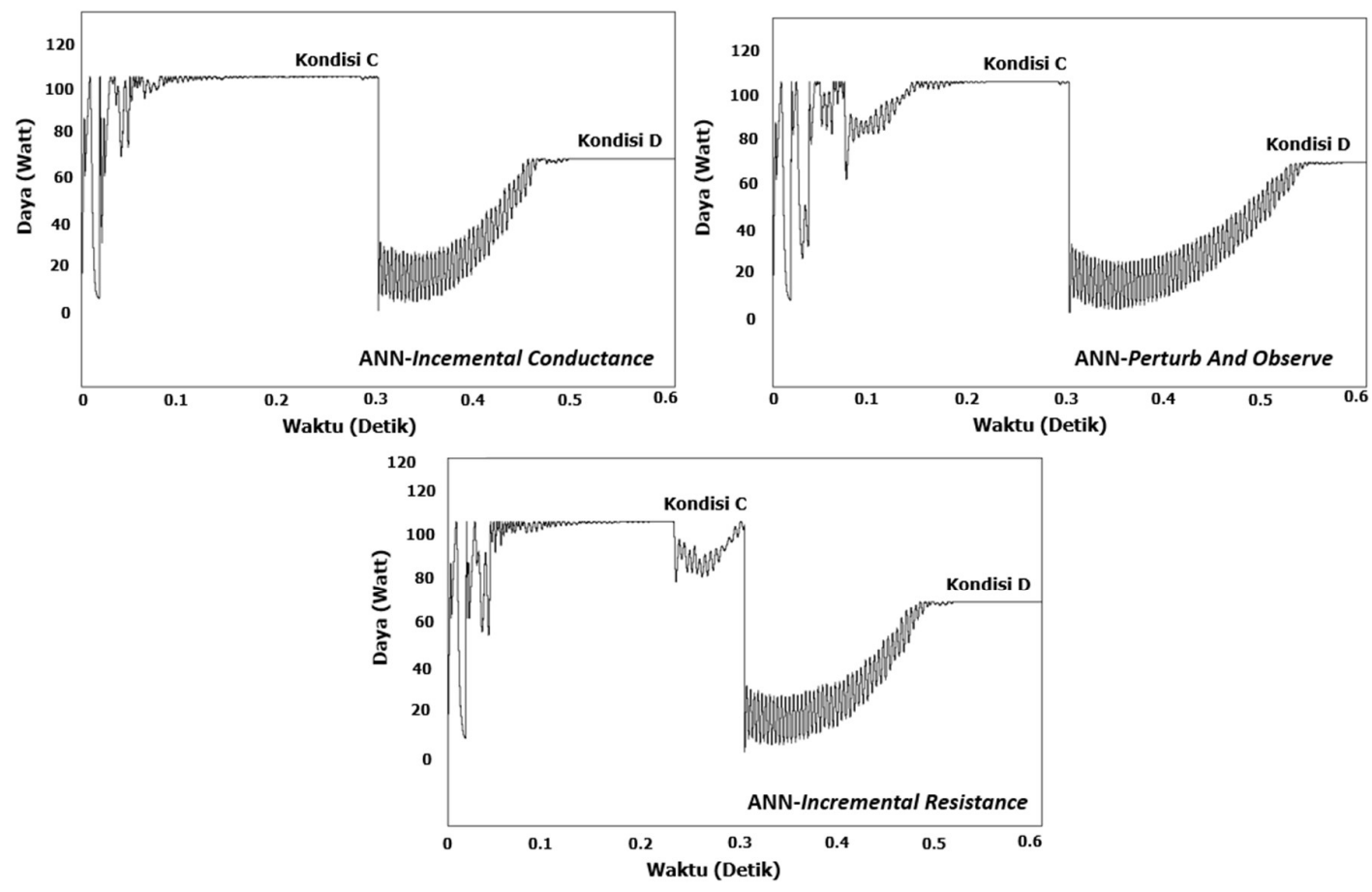

Gambar 13. Hasil Perbandingan Pengujian dengan Tiga Algoritma pada Nilai Radiasi Berubah-ubah

Tabel 3. Energi yang Dihasilkan oleh Algoritma

\begin{tabular}{|l|c|}
\hline \multicolumn{1}{|c|}{ Algoritma } & Energi (Ws) \\
\hline ANN-Incremental Conductance & 1926.15 \\
\hline ANN-Perturb and Observe & 1669.61 \\
\hline ANN-Incremental Resistance & 1814.69 \\
\hline
\end{tabular}

Tabel 3 menunjukkan bahwa algoritma yang diajukan yaitu ANN-Incremental Conductance menghasilkan energi yang lebih besar daripada algoritma ANN-Perturb and Observe dan algoritma ANN-Incremental Resistance dengan nilai 1926.15 Ws. 
Perbaikan MPPT Incremental Conductance menggunakan ANN pada Berbayang Sebagian dengan Hubungan Paralel

\section{KESIMPULAN}

Makalah ini menjelaskan tentang perbaikan algoritma Incremental Conductance untuk kondisi berbayang sebagian dengan hubungan paralel menggunakan Artificial Neural Network. Artificial Neural Network dapat mengidentifikasi kondisi berbayang sebagian yang terjadi pada panel surya, serta Artificial Neural Network juga dapat mengidentifikasi letak daerah Global Maximum Power Point (GMPP) dari kondisi berbayang sebagian. Sehingga Artificial Neural Network bisa menghasilkan posisi awal tracking yang tepat untuk algoritma Incremental Conductance agar tidak terjebak pada Local Maximum Power Point (LMPP). Hasil pengujian menunjukkan bahwa nilai daya maksimum yang dihasilkan oleh algoritma ANN-Incremental Conductance dapat mendekati nilai daya maksimum yang digunakan sebagai data learning. Algoritma ANN-Incremental Conductance juga memiliki kestabilan saat berada pada kondisi GMPP jika dibandingkan dengan ANN-Perturb and Observe, serta memiliki waktu yang lebih cepat mencapai GMPP. Energi yang dihasilkan juga lebih besar jika dibandingkan dengan kedua algoritma tersebut, yaitu dengan nilai 1926.15 Ws selama 0.6 detik.

\section{UCAPAN TERIMA KASIH}

Terima kasih kepada Kementerian Riset Teknologi dan Pendidikan Tinggi untuk pembiayaan dana riset kepada group riset Pusat Peneltian Green Energy and Sustainability di Politeknik Elektronika Negeri Surabaya sehingga riset ini bisa terselenggara dengan lancar dan baik.

\section{DAFTAR RUJUKAN}

Allataifeh, A. A., Bataineh, K., \& Al-Khedher, M. (2015). Maximum Power Point Tracking Using Fuzzy Logic Controller under Partial Conditions. Smart Grid and Renewable Energy, 6(1), 1-13.

Bouselham, L., Hajji, M., Hajji, B., \& Bouali, H. (2017). A New MPPT-based ANN for Photovoltaic System under Partial Shading Conditions. Energy Procedia, 111, 924-933.

BP Energy Outlook. (2019). Edition The Energy Outlook explores the forces shaping the global energy transition out to 2040 and the key uncertainties surrounding that. BP Energy Outlook 2019.

Elobaid, L. M., Abdelsalam, A. K., \& Zakzouk, E. E. (2015). Artificial neural network-based photovoltaic maximum power point tracking techniques: A survey. IET Renewable Power Generation.

Habibi, M. N., Ayub Windarko, N., \& Tjahjono, A. (2019). Hybrid Maximum Power Point Tracking Using Artificial Neural Network-Incremental Conduction with Short Circuit Current of Solar Panel. IES 2019 - International Electronics Symposium (IES): The Role of Techno-Intelligence in Creating an Open Energy System Towards Energy Democracy, Proceedings, 63-69.

Isaloo, B. A., \& Amiri, P. (2016). Improved variable step size incremental conductance MPPT 
method with high convergence speed for PV systems. Journal of Engineering Science and Technology, 11(4), 516-528.

Kamran, M., Mudassar, M., Fazal, M. R., Asghar, M. U., Bilal, M., \& Asghar, R. (2018). Implementation of improved Perturb \& Observe MPPT technique with confined search space for standalone photovoltaic system. Journal of King Saud University - Engineering Sciences.

Khadidja, S., Mountassar, M., \& M'Hamed, B. (2017). Comparative study of incremental conductance and perturb \& observe MPPT methods for photovoltaic system. International Conference on Green Energy and Conversion Systems, GECS .

Kurnia M, P., Ali, M., \& Katherin, I. (2013). Penelusuran Daya Maksimum Pada Panel Photovoltaic Menggunakan Kontrol Logika Fuzzy Di Kota Surabaya. Jurnal Teknik POMITS, 2(1), 135-140.

Mahmoud, Y. A., Xiao, W., \& Zeineldin, H. H. (2013). A parameterization approach for enhancing PV model accuracy. IEEE Transactions on Industrial Electronics, 60(12), 5708-5716.

Mohapatra, A., Nayak, B., Das, P., \& Mohanty, K. B. (2017). A review on MPPT techniques of PV system under partial shading condition. Renewable and Sustainable Energy Reviews, 80(February), 854-867.

Necaibia, S., Kelaiaia, M. S., Labar, H., Necaibia, A., \& Castronuovo, E. D. (2019). Enhanced auto-scaling incremental conductance MPPT method, implemented on low-cost microcontroller and SEPIC converter. Solar Energy, 180, 152-168.

Olalla, C., Clement, D., Rodriguez, M., \& Maksimovic, D. (2013). Architectures and control of submodule integrated dc-dc converters for photovoltaic applications. IEEE Transactions on Power Electronics, 28(6), 2980-2997.

Sera, D., Mathe, L., Kerekes, T., Spataru, S. V., \& Teodorescu, R. (2013). On the perturb-andobserve and incremental conductance mppt methods for PV systems. IEEE Journal of Photovoltaics, 3(3), 1070-1078.

Tamrakar, V., Gupta, S. C., \& Sawle, Y. (2016). Study of characteristics of single and double diode electrical equivalent circuit models of solar PV module. International Conference on Energy Systems and Applications, ICESA, 312-317.

Windarko, N. A., Habibi, M. N., Ari, M., Nugroho, B., \& Prasetyono, E. (2020). Simulator Panel Surya Ekonomis untuk Pengujian MPPT pada Kondisi Berbayang Sebagian ( Low Cost PV Photovoltaic Simulator for MPPT Testing under Partial Shading ). 9(1), 110-115. 